Gladkovska V.

\title{
RATIONALE FOR LOGISTICS OPERATOR INFRASTRUCTURE PARAMETERS
}

Представлена економіко-математична модель, яка дозволяє для транспортно-експедиторської компанії визначати перспективи ї присутності на розглянутих регіональних ринках в якості логістичного оператора. Ця модель також дозволяє встановлювати в процесі розвитку нові ринки для того, щоб виступати в якості складової логістичної інфраструктури регіонів.

Ключові слова: логістична інфраструктура регіонів, логістичний оператор, матеріальний потік, транспортно-експедиторська компанія.

\section{Introduction}

Freight forwarding companies that in the course of their development begin to provide logistics operator services enter a new market and become part of the logistics infrastructure of the region or several regions.

The concept of logistics infrastructure, as well as infrastructure in the general economic sense, can be considered from different points of view. But all of them boil down to the fact that in logistics, infrastructure, as well as in other areas, primarily plays an enabling role, and infrastructure activity is realized in the form of services.

Logistics infrastructure is a complex of interrelated elements that ensure the functioning of the system of procurement, supply, storage and delivery of products to the consumer. Under the logistics infrastructure is understood the market of logistics operators, transport and information systems.

The logistics operator becomes part of the logistics infrastructure of the region (country) and at the same time is an element of various logistics infrastructures in their narrow understanding.

Let's note that in the future, by the term «region» we will understand the area of the city, district or region - the content depends on the scale and strategic goals of the company for which the logistics infrastructure is designed. And the location of infrastructure is directly one of the most important factors affecting the configuration of the logistics system of enterprises, as well as the level of costs. Thus, the decision on the composition and location of the logistics infrastructure objects is relevant in the company's strategy.

\section{The object of research and its technological audit}

The object of research is the infrastructure of the logistics operator.

The infrastructure of the logistics operator is influenced by the factors that are presented in Fig. 1.
Factors of the infrastructure of the logistics operator can be divided into two categories - the factors of the external and internal environment. The external environment is directly influenced by the micro level, which in this case includes the logistics services market, the transport infrastructure that is fundamental in determining, for example, the location of the storage network. Among the factors of the internal environment of transport-forwarding companies, the already existing logistics infrastructure and the development strategy are decisive in this matter [1-4].

One of the most problematic places in designing a logistics infrastructure is that a freight forwarding company must take into account a number of interrelated factors that can affect it. This is due to the fact that one of the main is the structure of costs, which includes: transportation costs, permanent investment in infrastructure and its operation. And also the availability of vehicles, their number and brand, distribution centers, warehouses, their number, capacity and location. All these factors influencing determine an unlimited and constant amount of expenditure.

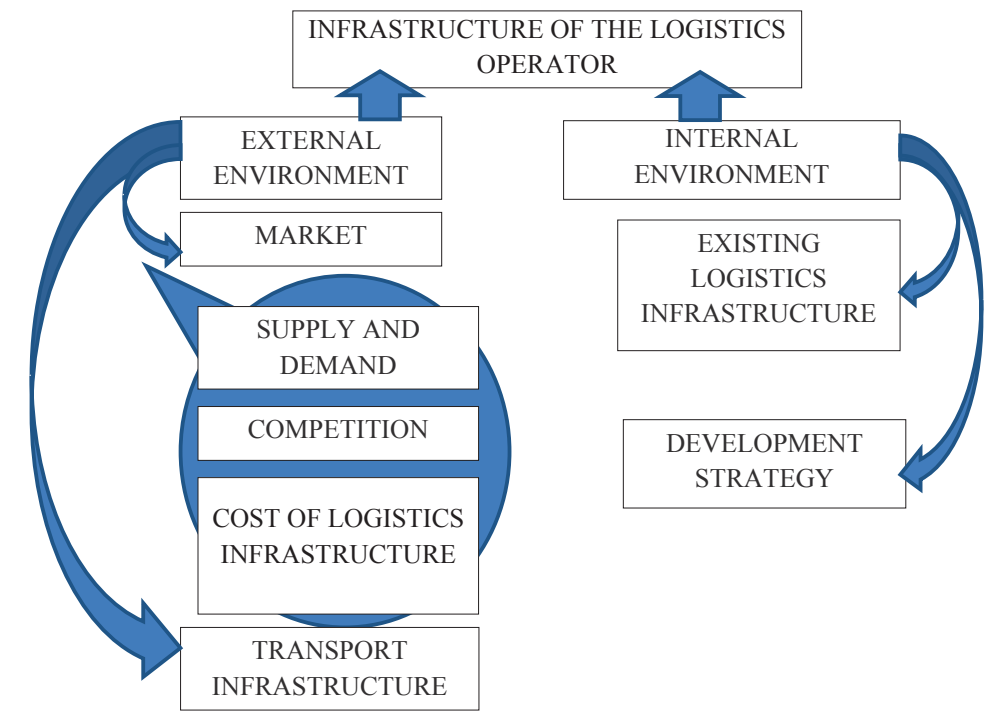

Fig. 1. Factors affecting the infrastructure of the logistics operator 
The reason for this is the lack of experimental data in this field of research, which would allow to describe the economic and mathematical model of the process of designing the infrastructure of a logistics operator and also to choose the direction for improving the work of the freight forwarding company in the field of distribution of warehouses.

\section{The aim and objectives of research}

The aim of research is development of an economic and mathematical model for determining the prospects for the presence of a freight forwarding company in the regional markets in question as a logistics operator.

To achieve this aim, it is necessary to solve the following tasks:

1. To identify the factors those influence the formation of the logistics operator infrastructure.

2. To determine the structure of costs of the logistics operator.

\section{Research of existing solutions of the problem}

Analyzing the market of transport and logistics services, the tasks of placing the warehouse network (distribution centers network) are often used in modern publications. For example, the author of [5] believes that the location of infrastructure objects directly affects the configuration of the logistics system of enterprises, as well as the level of costs. Thus, the decision on the composition and location of logistics infrastructure facilities is key to the company's strategy.

Let's note that the logistics systems, on the one hand, are «tied» in the design to the existing objects of the logistics infrastructure. On the other hand, the logistics infrastructure is replenished with facilities in accordance with the need for existing or projected logistics systems. Classical approaches are: the «center of gravity» method, the Weber model. At the heart of the classical approaches is the minimization of transportation costs.

The problem of forming a warehouse network or determining the location of a distribution center is studied in the work [6]. In this work it is noted that the process of making decisions on the choice of the location of distribution centers consists of several stages with a gradual transition from large regions to smaller ones, down to specific land plots.

At the present stage, there are methods that are the development of basic approaches in terms of the meaningfulness of tariffs and distances (for example, the replacement of distances by coordinates, distance by road, etc.). It should be noted that many studies in this area are focused on warehouse (terminal) networks of manufacturers or large distributors, when information about consumers and suppliers is quite specific.

The paper [7] is devoted to simulation modeling of the work of logistics distribution centers aimed at managing already created logistics centers and optimizing supplies in real time or designing infrastructure centers.

In works [8-10] it is noted that the efficiency of transport services for regional industrial consumers is to minimize the costs associated with transportation. These include the costs of bringing the goods to the final consumer, namely - distribution (distribution, or distribution of cargo flows in the delivery directions), for intermediate storage of cargo during the movement of goods and costs directly for transportation.

When designing the main parameters of the terminal network (the number and location of terminals in its composition), it is necessary to take into account not only the entire spectrum of costs accompanying transportation, but also the multivariance of possible spatial-quantitative network solutions [11-16].

\section{Methods of research}

When designing a logistics infrastructure, the freight forwarding company must take into account the cost structure, as well as the factors that affect them. Let's note that most of the factors affecting the infrastructure of the logistics operator determine its costs. Therefore, the formation of the logistics infrastructure is largely determined by the costs of its creation and operation.

The costs of a logistics operator associated with the operation of a logistics infrastructure can be presented in the form of three components:

- $A-$ transportation costs (expenses directly for transportation);

$-B$ - investment costs for the acquisition of vehicles and construction (acquisition, reconstruction) of warehouses (distribution centers);

- $C$ - operational costs associated with the operation of the warehouse network (here, too, rents in the case of renting storage facilities) and the maintenance of the fleet of vehicles (fixed costs).

The costs of group $A$ are determined mainly by the characteristics of the transport infrastructure of the region and the location of the storage network, as well as the type of used vehicles. In essence, these are variable costs of vehicles, if transportation does not involve the participation of several modes of transport, for example, delivery of goods in a container by sea, and then by road. In this case, in addition to variable costs for vehicles, this group includes the costs of transportation by other modes of transport (not owned by the operator).

The structure of expenses of group $A$ depends on what kinds of expenses the logistics operator assumes. If it services goods, only have arrived (for example, by sea), then the costs of maritime transportation are no longer included in this group. If the operator assumes the responsibility for the delivery of goods «from door to door», the inclusion of transportation costs by other modes of transport will be determined by the transport terms of the contract.

Thus, transportation costs of group $A$ can be divided into two categories:

- A1 - variable costs for vehicles belonging to the operator;

- $A 2$ - transportation costs by other modes of transport and vehicles that do not belong to the operator, within its responsibility in accordance with the transport terms of the contract and the contract with logistics services.

The costs of group $B$, on the one hand, are determined by the cost of the logistics infrastructure, and, on the other hand, by the investment opportunities of the operator. Also let's note that the costs of group $B$ depend on the financing option for creating a logistics infrastructure.

In turn, the cost of the logistics infrastructure depends on its type, condition, etc. For example, the cost of the composition is determined by its size, type of equipment (ware- 
house infrastructure) and location. So, in different regions the cost of the same version of the composition can be different. Also, the cost of renting a warehouse in a group of expenses will be different.

Therefore, when determining the location of a warehouse, it is important not only to account for transportation costs (as indicated in virtually all publications), but also investment and operating costs. This should be taken into account when designing the logistics operator infrastructure.

The costs of group $C$ are fixed costs for vehicles and operating costs for syllables (including rental).

The main parameters of the logistics infrastructure in the $i$-th region:

1) the number, types and brands of vehicles (in most cases, motor vehicles);

2) total capacity (capacity of warehouses).

Let's note that the assignment of fixed and variable costs for vehicles to different groups, in contrast to syllable costs, is determined by the fact that the variable costs for vehicles depend on the characteristics of the transport infrastructure (with fixed characteristics of vehicles) and the location of warehouses. Variable costs for syllables are determined by the characteristics served by material flows (with fixed characteristics of warehouses) [17, 18].

\section{Research results}

It should be noted that at the stage of strategic decision-making on logistics infrastructure, the location of the warehouse network is not the subject of research, therefore, in the framework of this task, the total storage capacity requirement is determined.

Let's introduce the notation:

$X_{k l}^{t r i}$ - number of vehicles of the $k$-th type of $l$ - brands (manufacturer) that serve the $i$-th region, $k=\overline{1, K}, l=\overline{1, L}$, where $K$ - the number of types of considered vehicles; $L$ - number of considered brands (manufacturers). Let's note that modern manufacturers of vehicles (namely, it is considered as a vehicle in the logistics infrastructure) produce a wide range of types (isothermal, refrigerated, etc.), so it is considered that $K$ is not related to $l$.

$X^{\omega, i}$ - the capacity of warehouses in the $i$-th region.

Also, let's introduce the parameter $I^{\infty, i}$, characterizing the level of the equipment of the composition. In order to form a set of possible values of $I^{e, i}$, it is possible to develop an assessment scale or use a generally accepted variant of classification of warehouses by category.

The category «A+» combines warehouses with the most convenient and profitable ones from the point of view of logistics. Such warehouses have sufficient areas, offices, warehousing and loading equipment. The cost of renting such premises is high.

Warehouses of category «A» are slightly cheaper, although they meet many requirements inherent in the previous category. This is also one-story capital facilities with a developed infrastructure.

The category « $B+»$ requires the warehouse to have a ceiling height of at least $8 \mathrm{~m}$. The composition should be located near major roads, have convenient access roads and a place for maneuvering heavy vehicles.

Premises of the category «B» can be either single- or double-deck. Category «C» includes storage rooms with ceilings of at least $4 \mathrm{~m}$. This can be both capital facilities and insulated hangars.
Thus, using the generally accepted classification of warehouses, it can be assumed that $I^{w, i i} \in\{A+, A, B+, B, C\}$. Warehouses of category $C$ and $D$ are not considered as possible options, as they are not used by logistic operators.

In the most general form, the task of designing a logistics infrastructure can be represented as follows:

- to determine $X_{k l}^{t r, i}, X^{w, i i}, I^{w, i i}$ for which during the period under consideration $T$ :

$$
\begin{aligned}
& \sum_{i=1}^{n}\left(R_{A}^{i}\left(\left.X_{k l}^{t r, i}\right|_{k=\overline{1, K}, l=\overline{1, L}}, X^{w, i i}, I^{w, i i}, \Lambda^{i}\right)+\right. \\
& \left.+R_{C}^{i}\left(\left.X_{k l}^{t r, i}\right|_{k=\overline{1, K}, l=\overline{1, L}, \bar{L}}, X^{w, i i}, I^{w, i i}, \Lambda^{i}\right)\right) \rightarrow \min ,
\end{aligned}
$$

that is, given the integral intensity of material flows $\Lambda^{i}$, the costs of transportation $\Lambda^{i}$ and infrastructure operation $R_{C}^{i}$ will be minimal. At the same time, investments in the logistics infrastructure are limited by the financial capabilities of the company - operator $R^{\text {inv }}$. Investments should provide the necessary level of efficiency $E^{\text {ino }}$ both in general and in regions (depending on the strategic goals of the company and the specifics of the region.) For each region, one can establish its own level of efficiency $E^{\text {inzo,ii }}$ :

$$
\begin{aligned}
& \sum_{i=1}^{n}\left(R_{B}^{i}\left(\left.X_{k l}^{t r i,}\right|_{k=1, \overline{1}, l=\overline{1, L}}, X^{w, i i}, I^{w, i i}\right) \leq R^{i i n v},\right. \\
& \frac{\left(\sum_{i=1}^{n} \Pi^{i}\left(\left.X_{k l}^{t r, i i}\right|_{k=\overline{1, K}, l=\overline{1, L}}, X^{w, i i}, I^{w, i i}, \Lambda^{i}\right)\right)}{\left(\sum_{k=1}^{n} R_{B}^{i}\left(\left.X_{k l}^{t r, i i}\right|_{k=\overline{1, K}, l=\overline{1, L}}, X^{w, i i}, I^{w, i i}\right)\right)} \geq E^{i i n v}, \\
& \frac{\Pi^{i}\left(\left.X_{k l}^{t r, i i}\right|_{k=\overline{1, K}, l=\overline{1, L}}, X^{w, i i}, I^{w, i i}, \Lambda^{i}\right.}{R_{B}^{i}\left(\left.X_{k l}^{t r, i i}\right|_{k=\overline{1, K}, l=\overline{1, L},}, X^{w, i i}, I^{w, i i}\right)} \geq E^{i i n v, i i},(i=\overline{1, n}),
\end{aligned}
$$

where $\Pi^{i}\left(\left.X_{k l,}^{t r, i}\right|_{k=\overline{1, K}, l=\overline{1, L}}, X^{w, i i}, I^{w, i i}, \Lambda^{i}\right)$ - profit from the use of the logistics infrastructure of the $i$-th region $(i=\overline{1, n})$ :

$$
\begin{aligned}
& \Pi^{i}\left(\left.X_{k l}^{t r, i}\right|_{k=\overline{1, K}, l=\overline{1, L}}, X^{w, i i}, I^{w, i i}, \Lambda^{i}\right)= \\
& =D^{i}\left(\left.X_{k l}^{t r, i}\right|_{k=\overline{1, K}, l=\overline{1, L}}, X^{w, i i}, I^{w, i i}, \Lambda^{i}\right)- \\
& -\left(R_{A}^{i}\left(\left.X_{k l}^{t r, i}\right|_{k=\overline{1, K}, l=\overline{1, L}}, X^{w, i i}, I^{w, i i}, \Lambda^{i}\right)+\right. \\
& \left.+R_{C}^{i}\left(\left.X_{k l}^{t r, i}\right|_{k=\overline{1, K}, l=\overline{1, L},}, X^{w, i i}, I^{w, i i}, \Lambda^{i}\right)\right),
\end{aligned}
$$

where $D^{i}\left(\left.X_{k l}^{t r, i}\right|_{k=1, \bar{K}, l=\overline{1, L}}, X^{w, i i}, I^{w, i i}, \Lambda^{i}\right)$ - income from the use of logistics infrastructure.

Restrictions on investments can also be differentiated by region. For this situation:

$$
R_{B}^{i}\left(\left.X_{k l}^{t r, i}\right|_{k=\overline{1, K}, l=\overline{1, L}}, X^{w, i i}, I^{w, i i}\right) \leq R^{i n v v, i i}(i=\overline{1, n}),
$$

where $R^{i n v, i}-$ permissible amount of investment in the $i$-th region.

$$
\frac{\left(\sum_{i=1}^{n} \Pi^{i}\left(\left.X_{k l}^{t r, i i}\right|_{k=\overline{1, K}, l=\overline{1, L}}, X^{w, i i}, I^{w, i i}, \Lambda^{i}\right)\right)}{\left(\sum_{i=1}^{n} R_{B}^{i}\left(\left.X_{k l}^{t r, i i}\right|_{k=\overline{1, K}, l=\overline{1, L}}, X^{w, i i}, I^{w, i i}\right)\right)} \rightarrow \max
$$


As a rule, the logistics operator as the main competitive advantages should have: a low cost and a high level of organization of logistics processes. Therefore, in this research (1) is proposed as a criterion. Also let's note that (1) it is advisable to use as a criterion in those situations when the company sets as its goal the presence in the business and «covering» it with certain regions. Efficiency is seen as a promising goal.

To complete the simulation of this task, it is necessary to take into account the demand for operator services based on the projected infrastructure:

$$
\begin{aligned}
& X^{w, i i} \leq Q^{i}\left(\Lambda^{i}\right)(i=\overline{1, n}), \\
& \sum_{k=1}^{K} \sum_{l=1}^{L} P_{k l}^{t r, i} \cdot X_{k l}^{t r, i i} \leq P^{i}\left(\Lambda^{i}\right),(i=\overline{1, n}),
\end{aligned}
$$

where $Q^{i}\left(\Lambda^{i}\right)$ - the demand for warehouse services in the $i$-th region is determined on the basis of the intensity of the integral material flow $\Lambda^{i}$. The $Q^{i}$ definition should take into account: average storage time, required level of stocks, etc., that is a separate task and is beyond the scope of this research; $P_{k l}^{t r, i}$ - carrying capacity of vehicles of the $k$-th type $l$ - brands (manufacturer) that serve the $i$-th region, $k=\overline{1, K}, l=\overline{1, L} ; \quad P^{i}\left(\Lambda^{i}\right)-$ necessary total transport capacity of vehicles, which is determined on the basis of the intensity of the integral material flow $\Lambda^{i}$.

In the above arguments, the average value (mathematical expectation $\Lambda^{i}$ ) of a random variable $X^{i}$ is used as a characteristic of the material flow. But, since the intensity of the material flow is a random variable, the main commercial risk of creating a logistics infrastructure is associated with the deviation of the actual intensity from the average level $\Lambda^{i}$. For the adequacy of the model, it is necessary to take into account the existing risk associated with the deviation of the demand value adopted in the design, that is, consideration of uncertainty.

The objective function and constraints depend on the intensity of the material flow, but taking into account the uncertainty in the objective function and in the constraints will significantly complicate the model and increase the amount of information necessary for the implementation. Since the need for infrastructure is taken into account directly in (8), (9), let's consider it expedient to present only these limitations in $P$-type (2), that is:

$$
\begin{aligned}
& P\left\{X^{w, i i} \leq Q^{i}\left(X^{i}\right)\right\} \geq \alpha,(i=\overline{1, n}), \\
& P\left\{\sum_{k=1}^{K} \sum_{l=1}^{L} P_{k l}^{t r, i i} \cdot X_{k l}^{t r, i i} \leq P^{i}\left(X^{i}\right)\right\} \geq \beta,(i=\overline{1, n}),
\end{aligned}
$$

where $\alpha, \beta$ - given probabilities (may be identical); $X^{i}-$ random variable. Let's note that $Q^{i}\left(X^{i}\right)$ and $P^{i}\left(X^{i}\right)$ are functions of a random variable subject to the normal law. Due to the specifics of the technical and operational sense $Q^{i}\left(X^{i}\right)$ and $P^{i}\left(X^{i}\right)$, their principal appearance can be represented as follows:

$$
\begin{aligned}
& Q^{i}\left(X^{i}\right)=\mu^{i} \cdot X^{i}, \mu^{i} \geq 0, i=\overline{1, n}, \\
& P^{i}\left(X^{i}\right)=\lambda^{i} \cdot X^{i}, \lambda^{i} \geq 0, i=\overline{1, n},
\end{aligned}
$$

that is, they can be taken as linear functions by $X^{i}$. Indeed, if, for example, the entire material flow passes through the warehouse and $30 \%$ during a given unit of time should be present in the warehouse as a stock, then $\mu^{i}=1,3$.

So, according to the rules of probability theory, the mathematical expectations of random variables $Q^{i}\left(X^{i}\right)$ and $P^{i}\left(X^{i}\right)$ :

$$
\begin{aligned}
& M\left(Q^{i}\left(X^{i}\right)\right)=\mu^{i} \cdot \Lambda^{i}, \mu^{i} \geq 0, i=\overline{1, n}, \\
& M\left(P^{i}\left(X^{i}\right)\right)=\lambda^{i} \cdot \Lambda^{i}, \lambda^{i} \geq 0, i=\overline{1, n},
\end{aligned}
$$

and their mean-square deviations:

$$
\begin{aligned}
& \sigma\left(Q^{i}\left(X^{i}\right)\right)=\mu^{i} \cdot \sigma^{i}, \mu^{i} \geq 0, i=\overline{1, n}, \\
& \sigma\left(P^{i}\left(X^{i}\right)\right)=\lambda^{i} \cdot \sigma^{i}, \lambda^{i} \geq 0, i=\overline{1, n}, \\
& X^{w, i} \leq \mu^{i} \cdot \Lambda^{i}-t_{a} \mu^{i} \sigma^{i},(i=\overline{1, n}), \\
& \sum_{k=1}^{K} \sum_{l=1}^{L} P_{k l}^{t r, i} \cdot X_{k l}^{t r, i} \leq \lambda^{i} \cdot \Lambda^{i}-t_{\beta} \lambda^{i} \sigma^{i},(i=\overline{1, n}),
\end{aligned}
$$

where $t_{a}$ and $t_{\beta}$ - the value of the normalized random variable in the normal distribution law, corresponding to given levels of probabilities $\alpha, \beta$.

Range of control parameters:

$$
\begin{aligned}
& X^{t r} \geq 0, k=\overline{1, K}, l=\overline{1, L}, i=\overline{1, n}, \\
& X^{w, i} \in Z^{+} \cup\{0\}, i=\overline{1, n} .
\end{aligned}
$$

Thus, the economic-mathematical model (1)-(7), (18)-(21) describes the solution of the problem of designing the infrastructure of a logistics operator.

\section{SWOT analysis of research results}

Strengths. Among the strengths of this research, it should be noted that in the new classification of warehouses, the linking of warehousing properties to the years of their construction is specified. A compulsory requirement for class $A+$ warehousing is to provide a high turnover speed, the flexibility to store any type of cargo, and proximity to the main transport lines. Therefore, when determining the location of a warehouse, it is important not only transportation costs, but also investment and operating costs. This is one of the most important factors that must be taken into account when designing the infrastructure of a logistics operator. Therefore, the formation of the logistics infrastructure is largely determined by the costs of its creation and operation. The solution of this problem on the basis of the developed economic-mathematical model allows the transport and forwarding company to determine the prospects for its presence in the considered regional markets as a logistics operator.

Weaknesses. The weaknesses of this research are related to the fact that not all categories of warehouses are used as possible options. This is due to the fact that they are not used by logistic operators, therefore warehouses of categories $C$ and $D$ are not considered. Also, the statement 
of the problem does not provide for the specification of indicators and parameters for time intervals.

Opportunities. As a result of the lack of detailing the time intervals, the considered interval $T$ is divided into stages. This will allow to determine the step-by-step formation of the infrastructure taking into account, for example, the gradual increase in intensity served by material flows, as well as the opportunities for phased financing of infrastructure development. In the future, this will allow to enter new markets and become part of the logistics infrastructure of the regions. This will entail the development and increase of competitiveness of the freight forwarding company by attracting additional volumes of cargo, expanding the regions, increasing the number of vehicles, warehouses, etc.

Threats. Threats to implementation of the research findings are due to the fact that the complex of traditional freight forwarding services can be viewed from the perspective of quality and competitiveness. The necessary range of services that is provided in modern conditions requires its development to the required (reference) level. Therefore, when implementing the planned measures to develop the infrastructure of a logistics operator, the complexity manifests itself in two directions:

1) uncertainty of knowledge about the current state of the market and the company;

2) uncertainty of the future state of the external environment can't be completely and reliably described for the large volume of affecting factors, and with the practical impossibility of their reliable prediction.

Thus, the SWOT analysis of research results allows to determine the measures for the infrastructure development of the logistics operator that are relevant to the strategic decisions and are aimed at the future, and to determine the main directions for the successful achievement of the research objective.

\section{Conclusions}

1. The factors of the internal and external environment influencing the infrastructure of the logistics operator are determined. These factors include: the level of demand and supply, the state of the competitive environment, the cost of the logistics infrastructure, the state of the transport infrastructure in the region, the existing logistics infrastructure of the operator company and its development strategies. These factors influence the micro level, which in this case includes the market of logistics services transport infrastructure. This is fundamental in determining, for example, the location of the warehouse network.

2. The structure of the costs of the logistics operator is determined, which consists of transport, investment and operating costs. The study also highlighted that when designing the infrastructure of a logistics operator in determining the location of warehouses, it is important not only to account for transportation costs, but also investment and operating costs. These costs allow to fully take into account all factors affecting the costs of the logistics operator.

The economic-mathematical model is considered which allows freight forwarding company to identify prospects for its presence in the regional markets as a logistics operator. Parameters of the model management are the capacity and level of equipment of warehouses in the regions, the composition of the fleet (number and type of trucks).
The optimization criterion reflects the minimization of the costs of operating a logistics infrastructure that meets the basic logistics requirements. Limitations take into account the possibilities of financial resources for creating a logistics infrastructure, the need to ensure a certain level of economic efficiency of the logistics infrastructure by region, as well as the demand for logistics services. Given the uncertainty of demand, restrictions are introduced in the structure of the model. They take into account this fact.

Thus, an economic-mathematical model is developed that allows solving the problem of designing the infrastructure of a logistics operator. The model belongs to the class of non-linear programming problems can be solved using standard software.

\section{References}

1. Voskresenskaia, T. P. Innovatsionno-metodologicheskii podhod $\mathrm{k}$ obosnovaniiu sozdaniia v regione seti terminalov kak edinogo transportno-ekspeditsionnogo prostranstva (na primere Kemerovskoi oblasti) [Text] / T. P. Voskresenskaia, O. D. Pokrovskaia // Transport Urala. - 2010. - No. 1 (24). - P. 23-27.

2. Schnaars, S. P. Marketing Strategy: Customers and Competition [Text] / S. P. Schnaars. - New York: Free Press, 1998. - 240 p.

3. Boulding, W. A Dynamic Process Model of Service Quality: From Expectations to Behavioral Intentions [Text] / W. Boulding, A. Kalra, R. Staelin, V. A. Zeithaml // Journal of Marketing Research. - 1993. - Vol. 30, No. 1. - P. 7-27. doi:10.2307/3172510

4. Yudin, B. D. Matematicheskie metody upravleniia v usloviiah nepolnoi informatsii [Text] / B. D. Yudin. - Moscow: Sovetskoe radio, 1974 . $-400 \mathrm{p}$.

5. Ivanova, N. V. The factors of formation of logistics infrastructure in enterprises for the production of bottled drinking water [Electronic resource] / N. V. Ivanova // Management of Economic Systems: Scientific Electronic Journal. - 31.08.2012. - Available at: \www/ URL: http://uecs.ru/marketing/item/1517-2012-08-31-05-22-38

6. Konstantinov, R. V. Proektirovanie optimal'noi skladskoi seti [Electronic resource] / R. V. Konstantinov // Electronic scientific journal «Engineering Journal of Don». - 2011. - No. 4. Available at: \www/URL: http://ivdon.ru/magazine/archive/ n4y2011/581

7. Pokrovskaia, O. D. Algoritmizatsiia zadachi kompleksnogo rascheta parametrov terminal'noi seti regiona [Text] / O. D. Pokrovskaia, I. V. Voskresenskii // Transport Urala. - 2011. No. 1 (28). - P. 10-13.

8. Lychkina, N. N. Imitatsionnoe modelirovanie ekonomicheskih protsessov [Text]: Handbook / N. N. Lychkina. - Moscow: Infra-M, 2012. - 253 p.

9. Lychkina, N. N. Retrospektiva i perspektiva sistemnoi dinamiki. Analiz dinamiki razvitiia [Text] / N. N. Lychkina // Biznesinformatika. - 2009. - No. 3 (9). - P. 55-67.

10. Suslov, S. A. Imitatsionnaia model' - uzhe vpolne obychnaia sostavnaia chast' logisticheskih proektov [Text] / S. A. Suslov // Logistika. - 2012. - No. 2 (63). - P. 22.

11. Pride, W. M. Marketing [Text] / W. M. Pride, O. C. Ferrell. - South-Western College Pub, 2008. - Ed. 15. - 605 p.

12. Edvinsson, L. Intellectual Capital: Realizing Your Company's True Value by Finding Its Hidden Brainpower [Text] / L. Edvinsson, M. S. Malone. - New York: HarperBusiness, 1997. - 240 p.

13. Crama, Y. Optimal procurement decisions in the presence of total quantity discounts and alternative product recipes [Text] / Y. Crama, J. R. Pascual, A. Torres // European Journal of Operational Research. - 2004. - Vol. 159, No. 2. - P. 364-378. doi:10.1016/j.ejor.2003.08.021

14. Sergeev, V. I. Kliuchevye pokazateli effektivnosti logistiki [Electronic resource] / V. I. Sergeev // Tsentr dopolnitel'nogo obrazovaniia «Elitarium». - Available at: \www/URL: http:/ www.elitarium.ru/logistika-gruzoperevozki-transport-perevozkagruzov-uslugi-proizvoditelnost 
15. Lobo, A. Port Users' perspective of container transhipment business: hierarch y of service attributes and dimensions [Text] / A. Lobo, V. Jain // Singapore Maritime and Port Journal. 2002. - Vol. 4. - P. 154-161.

16. Prahalad, C. K. The Core Competence of the Corporation [Text] C. K. Prahalad, G. Hamel // Strategische Unternehmungsplanung / Strategische Unternehmungsführung. - Physica-Verlag HD, 1997. - P. 969-987. doi:10.1007/978-3-662-41482-8 46

17. Zeithaml, V. How Consumer Evaluation Processes Differ Between Goods and Services [Text] / V. Zeithaml; ed. by J. H. Donnelly, W. R. George // Marketing of Services. - Chicago: American Marketing Association, 1981. - P. 186-190.

18. Tolujew, J. Simulation logistischer Netze [Text] / J. Tolujew // Logistics and Supply Chain Management. - 2008. - No. 2 (25). Available at: \www/URL: http://www.lscm.ru/index.php/ru/ po-godam/item/1141

\section{ОБОСНОВАНИЕ ПАРАМЕТРОВ ИНФРАСТРУКТУРЫ} ЛОГИСТИЧЕСКОГО ОПЕРАТОРА

Представлена экономико-математическая модель, которая позволяет для транспортно-экспедиторской компании определять перспективы ее присутствия на рассматриваемых региональных рынках в качестве логистического оператора. Эта модель также позволяет устанавливать в процессе развития новые рынки для того, чтобы выступать в качестве составляющей логистической инфраструктуры регионов

ключевъе слова: логистическая инфраструктура регионов логистический оператор, материальный поток, транспортноэкспедиторская компания.

Gladkovska Valentyna, Postgraduate Student, Assistant, Depart ment of Exploitation of Marine Ports, Odessa National Marine University, Ukraine, ORCID: http://orcid.org/0000-0003-4077-6711

\section{Dolya C., Lyfenko S., Nesterenko 5., Vyatkin K.}

INFLUENCE OF FEATURES OF THE
TRANSPORT NETWORK PATTERN ON
THE HAUL CYCLE LENGTH BETWEEN
ITS NODES ON THE EXAMPLE OF THE
TRANSPORT NETWORK OF UKRAINE

Досліджено сучасні підходи щодо визначення впливу параметрів та малюнку дорожньої мережі на ефективність функціонування транспорту. Встановлено, що параметри міжобласних перевезень залежать від характеристик дуг та загального малюнку дорожньої мережі. Визначено поняття коефіщієнту прямолінійності дослідженої дорожньої мережі та розраховано його значення для дослідженої мережі.

Ключові слова: дорожня мережа, ефективність транспортного процесу, коефіцієнт прямолінійності мережі.

\section{Introduction}

Ensuring the stable functioning of passenger transport systems can be considered a priority for organizers of transport and carriers. In the case that passengers are provided with the opportunity to realize the need for moving in the most convenient way, it is the basis for maximum implementation of potential transport correspondence between the nodes of the transport network. The main factors that affect the actual indicators of passenger traffic between the nodes of the transport network include:

- potential correspondence;

- fare;

- haul cycle time;

- time of day of haul cycle;

- haul cycle comfort;

- regularity and frequency of the haul cycle;

- social and economic characteristics of population development in transport hubs.

It can be noted that the actual indicators of passenger traffic volumes need to be adjusted to take into account the characteristic seasonal or daily fluctuations.
In turn, the intercity passenger route transport system uses its monetary resources to ensure its activities. The planned arrival of a monetary resource to ensure the stable functioning and development of intercity passenger route transport systems is indisputably important. At the same time, the distribution of money flows between elements of the transport system in time and quantity is no less relevant. In conditions of a balanced flow of financial flows within the system, the quantitative sufficiency of this resource and its balanced use of the elements of the system, it is possible to plan and develop the industry as a whole.

\section{The object of research and its technological audit}

The object of research is the state transport network on the example of Ukraine. This research examines the network of roads, which formed a modern transport network. The considered road network consists of more than 70 thousand arcs and nodes, which describe the routes of interregional, regional, international and regional significance. 